\title{
Room temperature ultrahigh pressure extraction in big beautiful crape myrtle leaf $2-\alpha$ hydroxyursolic acid
}

\author{
Qin $\mathrm{Xia}^{\dagger}$, Ren Xiaoyan and Li Hong \\ Department of Chemistry Engineering, Huainan Union University, \\ Huainan, 232001, China \\ Email:25854231@qq.com
}

\begin{abstract}
On the basis of single factor experiment, orthogonal test method for 2- $\alpha$ hydroxy for optimizing the extraction technology of ursolic acid, choose L9 (34) orthogonal experiment was carried out to $2-\alpha$ hydroxy yield of ursolic acid as index, at room temperature $\left(25^{\circ} \mathrm{C}\right)$ under ultra-high pressure, holding time, b Alcohol volume fraction and solid liquid ratio $(\mathrm{g}: \mathrm{mL})$ on $2-\alpha$ hydroxyursolic acid yield. Get the best process conditions for ultra-high pressure $300 \mathrm{MPa}$, the holding time for $5 \mathrm{~min}$, volume fraction of $90 \%$ ethanol, and solid-liquid ratio $1: 15$, extracting 3 times.2- $\alpha$ hydroxyursolic acid to obtain rate can be Up to $0.415 \%$.
\end{abstract}

Keywords: ultra-high pressure; big flowers crape myrtle; $2-\alpha$ hydroxyursolic acid.

Big beautiful crape myrtle for the willow branch deciduous trees, grow mainly in Australia and tropical Asia tate, our country guangdong, guangxi, hainan and fujian province have grown, such as tree height $5 \sim 15 \mathrm{~m}$, leaf $12 \sim 25 \mathrm{~cm}$ long, in the Philippines and other Asian countries the home, big beautiful crape myrtle is called banaba, big beautiful crape myrtle leaf, flower, fruit and stem are traditionally used to make health drink. Studies have shown that large purple flower extract with sugar, lipid, oxidation, and other functions [1-4], especially in hypoglycemic effect has been widely concerned. The main big crape myrtle fall blood sugar. 2- $\alpha$ hydroxyursolic acid such as triterpene composition [1], therefore, to extract large flowers crape myrtle 2- $\alpha$ hydroxyursolic acid composition, the development and utilization of large flowers crape myrtle. Resources is of great significance. Ultrahigh pressure extraction technology is in the normal temperature condition, the extraction of effective components in Chinese medicine raw materials of new technology [5].With the decoction Method, reflux method and soxhlet extraction, compared to the traditional extraction technology such as ultrahigh pressure extraction technology can greatly shorten the extraction time, lower energy consumption, reduce noise. Quality, improve the yield of active ingredients, and ultrahigh pressure extraction was conducted at room temperature, to avoid the effective component structural changes caused by heat effect. Losses and a fall in the physiological 
activity, and ultrahigh pressure extraction was conducted in a closed environment, no solvent volatilization, so the skill. More in line with the "green" environmental protection requirements. Based on this, the author studied the ultra-high pressure treatment on large flowers crape myrtle leaf 2- $\alpha$ hydroxyursolic acid extraction, the influence of different pressure, pressure time, ethanol volume fraction and the solid-liquid ratio, compare the extraction efficiency, the optimum extraction conditions.

\section{Experimental}

\subsection{Instruments, reagents and materials}

Instrument Agilent1100 highly effective liquid phase color spectrometer, Agilent companies in the United States; HH - type 2 digital constant temperature water-bath water, changzhou guohua electric appliance co., LTD. Du fu SHB $\mathrm{C}$ circulating water multi-purpose vacuum pump, zheng zhou instrument factory; SBW - 1 rotary evaporator, Shanghai shenbo instruments; FA1104 electronic balance, Shanghai fine balance in the factory. $2 \alpha$-hydroxyursolic acid reference substance provided by the Chromadex companies in the United States, water for the steam, acetonitrile, methanol as the chromatography is pure. The reagents are analytically pure.Material big beautiful crape myrtle collected from guangdong, vacuum drying, crushing and set aside.

\subsection{2- $\alpha$ hydroxyursolic acid method}

According to a certain amount of large flowers crape myrtle leaf powder, adding different volume fraction of ethanol solution, mix into suspension. In polyethylene plastic bags. Vacuum packaging, packaging the sample after soaking in high pressure vessel in pressure transfer medium oil, high pressure processing suspension, processing after filtration, removal of solid particles. To extract, extract three times, the extracted liquid, is applied to the analysis of two- $\alpha$ hydroxyursolic acid yield.

\section{Results and Discussion}

\subsection{2- $\alpha$ hydroxyursolic acid extracting single factor experiment}

Respectively big crape myrtle leaf with 0, 100, 200, 300, 400 and $200 \mathrm{MPa}$ high-pressure processing, ultrahigh pressure time $5 \mathrm{~min}$, the volume fraction of $90 \%$ ethanol and solid liquid ratio $(\mathrm{g}: \mathrm{mL}$, similarly hereinafter) 1:20, the results are shown in figure1 (a).

The result shows that after high pressure treatment, extraction efficiency 
greatly improved, and the higher the pressure, the greater the extraction efficiency. Generally considered high impact on the cell wall and cell membrane, make different degrees of cell disruption, reduce the mass transfer resistance of effective ingredients, active ingredients fully exposed, so that composition of stripping more quickly, completely improve the rate, as shown in figure 1 (a), pressure between $0 \sim 300 \mathrm{MPa}$, along with the increase of the pressure increase extraction yield, the linear positive correlation, in this pressure range, with the increase of pressure, effective component of mass transfer rate is accelerated, the number of cell wall and cell membrane was damaged may also increase, thus caused the withdrawal rate with the increase of the pressure and improve the phenomenon. Pressure is greater than $300 \mathrm{MPa}$, no significant changes, with the increase of the pressure ratio shows that the critical value of $300 \mathrm{MPa}$ is extraction pressure, when pressure is greater than the critical value, the mass transfer rate of effective components while fast, but stress to cells had no significant effect, therefore no significant change with the increase of the pressure extraction yield.

In the influence of the holding time In the volume fraction of $90 \%$ ethanol, solid-liquid ratio 1:20, $300 \mathrm{MPa}$ ultrahigh pressure processing under different time, the results are shown in figure 1 (b).By the graph, you can see that in the first $5 \mathrm{~min}, 2-\alpha$ hydroxyursolic acid yield increases over time, the holding time between $5 \sim 20 \mathrm{~min}$, extraction yield basic don't change. Pressure treatment process is to pressure for the material, first keep a certain time, and then all of a sudden pressure release, causing a sharp rise in the cells inside and outside differential pressure, in order to make the inclusions released cells. Visible 2- $\alpha$ hydroxyursolic acid dissociation outside the cells mainly in the instant pressure, pressure time for its impact is not big, from the point of view of saving energy and time, select the holding time below $5 \mathrm{~min}$.

The influence of ethanol volume fraction The extraction pressure $300 \mathrm{MPa}$, the holding time for $5 \mathrm{~min}$, and under the condition of solid-liquid ratio 1:20 different volume fraction of ethanol on 2- $\alpha$ hydroxy effects of ursolic acid yield as shown in figure $1(\mathrm{c})$. 


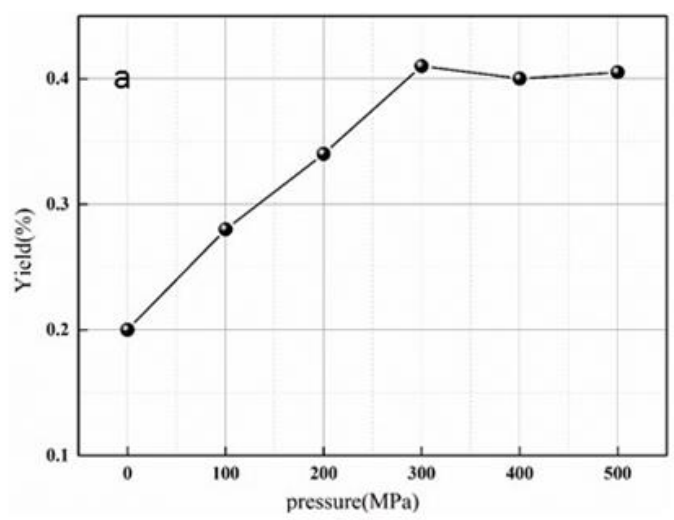

Figure 1 (a)

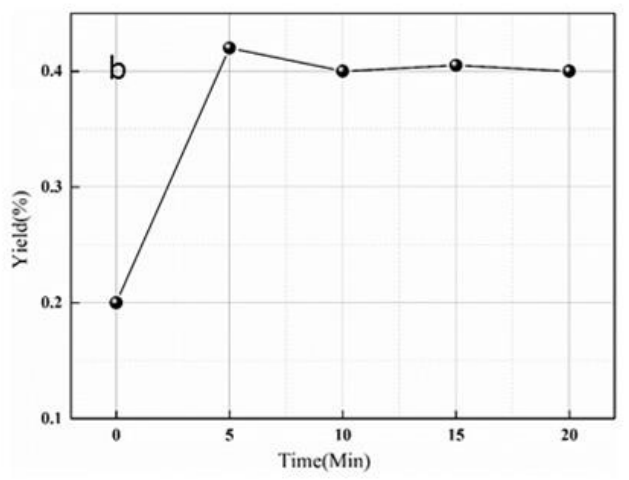

Figure $1(b)$

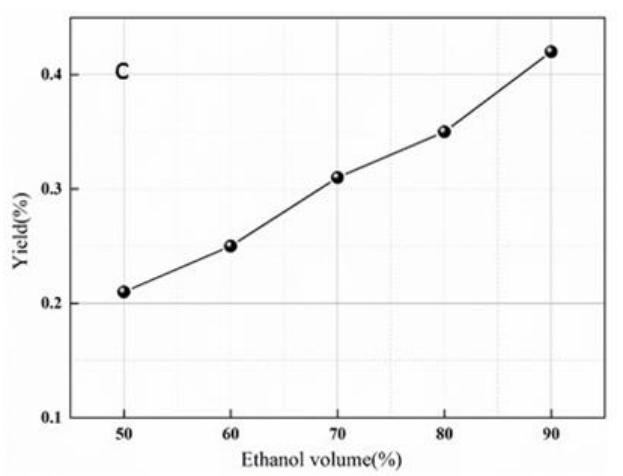

Figure 1(c)

Fig.1 Effects of SHP(a), SHP time(b) and ethanol volume part (c) on hydroxyursolic acid yield 
As the ethanol volume fraction increased, 2- $\alpha$ hydroxyursolic acid yield increase, this is due to the higher ethanol volume fraction and2- $\alpha$ hydroxy the more similar the polarity of ursolic acid, so choose ethanol volume fraction of $90 \%$ or so.

\section{Conclusion}

1. Ultrahigh pressure extraction 2 alpha hydroxy ursolic acid yield the best process conditions for pressure $300 \mathrm{MPa}$, the holding time is $5 \mathrm{~min}$, volume fraction of $90 \%$ ethanol, and solid-liquid ratio 1:15, extracting 3 times, 2 alpha hydroxy ursolic acid yield can reach $0.415 \%$.

2. Ultrahigh pressure extraction in big beautiful crape myrtle leaf 2 alpha hydroxy ursolic acid, time is short, high yield, in the extraction of natural products has a good application prospect.

\section{Acknowledgements}

The authors acknowledge funding supported in part by Anhui provincial natural science research project in colleges and universities (Nos. KJ2014A235), the excellent young talents in colleges and universities in Anhui province support plan in 2014, Anhui provincial natural science research project in colleges and universities (Nos. KJ2015A430), Key Project of Anhui Young Talents Fund(2013SQRL139ZD)

\section{References}

1. Y. Da, J. T. Chen and T. Masuda, Effectiveness and safety of banaba table containing extract from banaba in patients with mile type diabetes. Japanese Pharmacology and Therapeutics, 829, 27, 1999.

2. S. Mamoto, H. Kogami and K. Kohata, Glucose effect on blood glucose in rats. Yakuri to Chirty, 1075, 27, 1999.

3. U. Omonori, Antiobesity activity of extracts from Lagerstroemi a specious leave son female KK-Aymice. Journal of Nutritional Science and Vitaminology, 791, 45, 1999.

4. M. K, Masumizu, Antioxidative activity of water extracts of Lagerstroemia speciose leaves. Bioscience Biotechnology and Biochemistry, 1772, 61, 1997.

5. S. Q. Hang. Novel high pressure extraction technology, International Journal of Pharmaceutics, 471, 278, 2004. 